\title{
Effect of temperature and relative humidity on the stability of infectious porcine reproductive and respiratory syndrome virus in aerosols
}

\author{
Joseph HermanN ${ }^{\mathrm{a}}$, Steve HoFF $^{\mathrm{b}}$, Claudia MUÑOZ-ZANZI ${ }^{\mathrm{c}}$, \\ Kyoung-Jin YOON ${ }^{\mathrm{a}}$, Michael RoOF ${ }^{\mathrm{d}}$, Anna BURKHARDT ${ }^{\mathrm{a}}$, \\ Jeffrey ZIMMERMAN ${ }^{\mathrm{a} *}$ \\ ${ }^{a}$ Department of Veterinary Diagnostic and Production Animal Medicine, College of Veterinary \\ Medicine, Iowa State University, Ames, Iowa 50011-1250, USA \\ ${ }^{\mathrm{b}}$ Department of Agriculture and Biosystems Engineering, College of Agriculture, Iowa State University, \\ Ames, Iowa 50011-1250, USA \\ ${ }^{c}$ Division of Epidemiology and Community Health, School of Public Health, University of Minnesota, \\ Minneapolis, MN 55454, USA \\ ${ }^{\mathrm{d}}$ Boehringer Ingelheim Vetmedica, Inc., 2501 North Loop Dr., Suite 1000, Ames, Iowa 50010, USA
}

(Received 7 July 2006; accepted 13 September 2006)

\begin{abstract}
The objective of this experiment was to describe the stability of airborne infectious porcine reproductive and respiratory syndrome virus (PRRSV) as a function of temperature and relative humidity. A cloud of infectious PRRSV was aerosolized using 24-jet Collison nebulizer into a dynamic aerosol toroid (DAT) maintained at a specific temperature and relative humidity. The PRRSV cloud within the DAT was sampled repeatedly over time using SKC BioSampler ${ }^{\circledR}$ impingers and the total viral RNA (RT-PCR) and concentration of infectious PRRSV (TCID 50 ) in the air samples was determined. As measured by quantitative RT-PCR, PRRSV RNA was stable under the conditions evaluated in this study. Thus, a comparison of viral RNA and Rhodamine B dye, a physical tracer, found no significant difference in the slopes of the lines. Titers of infectious virus were plotted by time and the half-life $(T 1 / 2)$ of infectious PRRSV was calculated using linear regression analysis. An analysis of the results showed that aerosolized PRRSV was more stable at lower temperatures and/or lower relative humidity, but temperature had a greater effect on the $T 1 / 2$ of PRRSV than relative humidity. Based on these results, an equation was derived to predict the $T 1 / 2$ of infectious airborne PRRSV for any combination of environmental temperature and relative humidity.
\end{abstract}

aerosol / virus stability / PRRSV / relative humidity / temperature

\section{INTRODUCTION}

Porcine reproductive and respiratory syndrome virus (PRRSV) is an enveloped RNA virus in the family Arteriviridae

*Corresponding author: jjzimm@iastate.edu within the order Nidovirales [6, 8, 32, 35]. Herds clinically affected by PRRSV infection exhibit lower farrowing rates, fewer piglets weaned, slower growth rates, lower growth efficiency, and increased mortality. The effects of PRRSV on swine production are significant and direct losses from 
PRRSV were estimated to cost swine producers in the United States $\$ 560$ million annually [34].

A recently emerged virus, PRRSV was first isolated at the Central Veterinary Institute (Lelystad, the Netherlands) on porcine alveolar macrophage cultures from specimens obtained from herds undergoing severe reproductive disorders [31]. Following its introduction into the domestic swine population, probably some time in the 1970's, the virus spread rapidly and at present, the herd-level prevalence of infection generally exceeds $60 \%$ in swine-dense regions of the world [46].

Reliable methods to prevent, control, and/or eliminate PRRSV have not been achieved, in part, because our understanding of the PRRSV transmission cycle in domestic swine is still incomplete. It is known that pigs may become infected via exposure to PRRSV by any of several routes: intranasal $[18,45]$, intramuscular $[18,45]$, oral $[18,28,29,42]$, intrauterine [7], and vaginal [3, 17, 44]. Transmission via aerosols also occurs and was once considered the primary route of PRRSV transmission ${ }^{1}$, but it has been difficult to consistently reproduce airborne transmission of PRRSV from infected to susceptible pigs under experimental conditions $[4,11,15,25,26,40,41,43]$. Inconsistent replication of airborne transmission of PRRSV under experimental conditions suggests that we do not understand the conditions required for its occurrence. To address this lack of consistent data, we evaluated one of the stages of the process, i.e., stability of infectious PRRSV in aerosols as a function of temperature and relative

\footnotetext{
${ }^{1}$ Anon., The new pig disease: Conclusions reached at the seminar, in: The new pig disease, Porcine reproductive and respiratory syndrome, A report on the seminar/workshop held in Brussels on 29-30 April 1991 and organized by the European Commission Directorate General for Agriculture, 1991, pp. 82-86.
}

humidity. Since the stability of aerosolized viruses is a function of atmospheric conditions, the objective of this experiment was to derive an equation that would predict the half-life $(T 1 / 2)$ of aerosolized infectious PRRSV as a function of relative humidity and temperature. Half-life is the time in which the quantity of a substance declines by one-half [5]. T1/2 can be calculated for any factor that decreases exponentially with time.

\section{MATERIALS AND METHODS}

\subsection{Experimental design}

A suspension of PRRSV was aerosolized into a dynamic aerosol toroid (DAT) [16] rotating at 5 revolutions per minute and maintained at a pre-determined temperature and relative humidity. The cloud of PRRSV contained within the DAT was sampled repeatedly over time, the concentration of infectious PRRSV $\left(\mathrm{TCID}_{50}\right)$ in the samples was determined, and the $T 1 / 2$ for the specific combination of relative humidity and temperature was estimated based on the inactivation of infectious virus observed over time. A total of $18 T 1 / 2$ estimates were used in a regression analysis to derive an equation estimating the $T 1 / 2$ of aerosolized PRRSV for any combination of temperature and relative humidity.

\subsection{Virus and cells}

The North American prototype PRRSV ATCC VR-2332 (American Type Culture Collection, Manassas, VA, USA) was used in this study. The complete virus genomic sequence has been published (GenBank accession number PRU87392). Virus propagation and microinfectivity assays were performed on MARC-145 cells (National Veterinary Service Laboratory, Ames, IA, 
USA), a clone of the African monkey kidney cell line MA-104 that is considered highly permissive for PRRSV [23].

\subsection{Virus propagation}

Virus was propagated on 24 h-old MA-104 cells prepared in $1750 \mathrm{~cm}^{2}$ roller bottles (Corning, 430699, Corning, NY, USA) containing MEM growth medium: MEM (Sigma Chemical Co., M4655, St. Louis, MO, USA) supplemented with $10 \%$ fetal bovine serum (Sigma, F4922), $50 \mu \mathrm{g} / \mathrm{mL}$ gentamicin (Sigma, G1272), $100 \mathrm{IU} / \mathrm{mL}$ penicillin (Sigma, G6784), $100 \mathrm{mg} / \mathrm{mL}$ streptomycin (Sigma, G6784), and $0.25 \mu \mathrm{g} / \mathrm{mL}$ amphotericin B (Sigma, A4888). After $24 \mathrm{~h}$ at $37{ }^{\circ} \mathrm{C}$ in a humidified $5 \% \mathrm{CO}_{2}$ incubator, the MEM growth medium was discarded and the bottles inoculated with $5 \mathrm{~mL}$ of PRRSV isolate VR-2332 at a titer of $10^{6} \mathrm{TCID}_{50} / \mathrm{mL}$ in maintenance medium: $50 \mathrm{~mL}$ of MEM supplemented with $2 \%$ FBS, $50 \mu \mathrm{g} / \mathrm{mL}$ gentamicin, $100 \mathrm{IU} / \mathrm{mL}$ penicillin, $100 \mu \mathrm{g} / \mathrm{mL}$ streptomycin, and $0.25 \mu \mathrm{g} / \mathrm{mL}$ amphotericin B. After $2 \mathrm{~h}$ at $37{ }^{\circ} \mathrm{C}$ in a humidified $5 \% \mathrm{CO}_{2}$ incubator, the inoculum was discarded and $300 \mathrm{~mL}$ of maintenance medium was added. Thereafter, cells were examined for cytopathic effect (CPE) daily. When 75\% CPE was observed, the medium was freeze-thawed $\left(-80{ }^{\circ} \mathrm{C} / 25^{\circ} \mathrm{C}\right)$ and cell lysates were harvested. The supernatant was centrifuged at $17696 \times g$ for $10 \mathrm{~min}$ and pooled. The supernatant harvested from the roller bottles was processed to increase virus titer using a Prep/Scale spiral wound ultrafiltration module (Model CDUF 001 LH, Millipore, Billerica, MA, USA) set to maintain a pressure of $1.40 \mathrm{~kg} / \mathrm{cm}$. Approximately $10 \mathrm{~L}$ of supernatant was reduced to approximately one liter of virus stock. The pooled virus stock was aliquoted into $10 \mathrm{~mL}$ volumes and stored at $-80^{\circ} \mathrm{C}$ until used.

\subsection{Dynamic aerosol toroid (DAT)}

The stainless steel DAT used in this study (Fig. 1) measured 24 inches $(60.9 \mathrm{~cm})$ in diameter by 18 inches $(45.7 \mathrm{~cm})$ deep, thus providing a total volume of $133 \mathrm{~L}$. A variable speed motor (BHLW15L-120T-D2, Brother Gearmotors, Bridgewater, NJ, USA) rotated the DAT at 5 revolutions per minute (RPMs). The rotation of the DAT maintained the aerosolized particles in suspension and reduced the rate of physical loss through sedimentation $[16,37,39]$. Three ports, equally spaced on the circumference of the DAT and equipped with externally mounted hepa-filters (Fisher Scientific, 18-999-2574, Hampton, NH, USA), allowed for pressure equilibration during nebulization (introduction of air) and impingement (extraction of air).

For environmental control, the DAT was housed in a modified glove box designed to maintain temperatures from $2{ }^{\circ} \mathrm{C}$ to $40{ }^{\circ} \mathrm{C}$ (SS Series 600, 1695-03-36231, Terra Universal, Inc., Anaheim, CA, USA). Prior to aerosolization of PRRSV, the desired temperature and relative humidity were stabilized inside the glove box and DAT. Higher relative humidity was achieved within the glove box by generating steam (Steam Dragon ${ }^{\circledR}$, Newall Manufactoring Co., Chicago, IL, USA) using filtered (Millipore, Super-Q, ZFSQ115P4, cartridges, CDMB01204, CDAC01204, CP2001003, PMEG09002), sterilized water. Lower relative humidity was achieved by drying the air within the glove box (NitroWatch ${ }^{\circledR}$, Terra Universal, 9670-00) with $99.995 \%$ pure $\mathrm{N}_{2}$ gas (Chemistry stores, 1600.0085, Ames, IA, USA). Relative humidity and temperature within the glove box were continuously monitored (Dwyer Model 657 relative humidity/temperature transmitter, Dwyer Instruments, Inc., Michigan City, IN, USA). In addition, relative humidity and temperature within the DAT were independently measured using a 


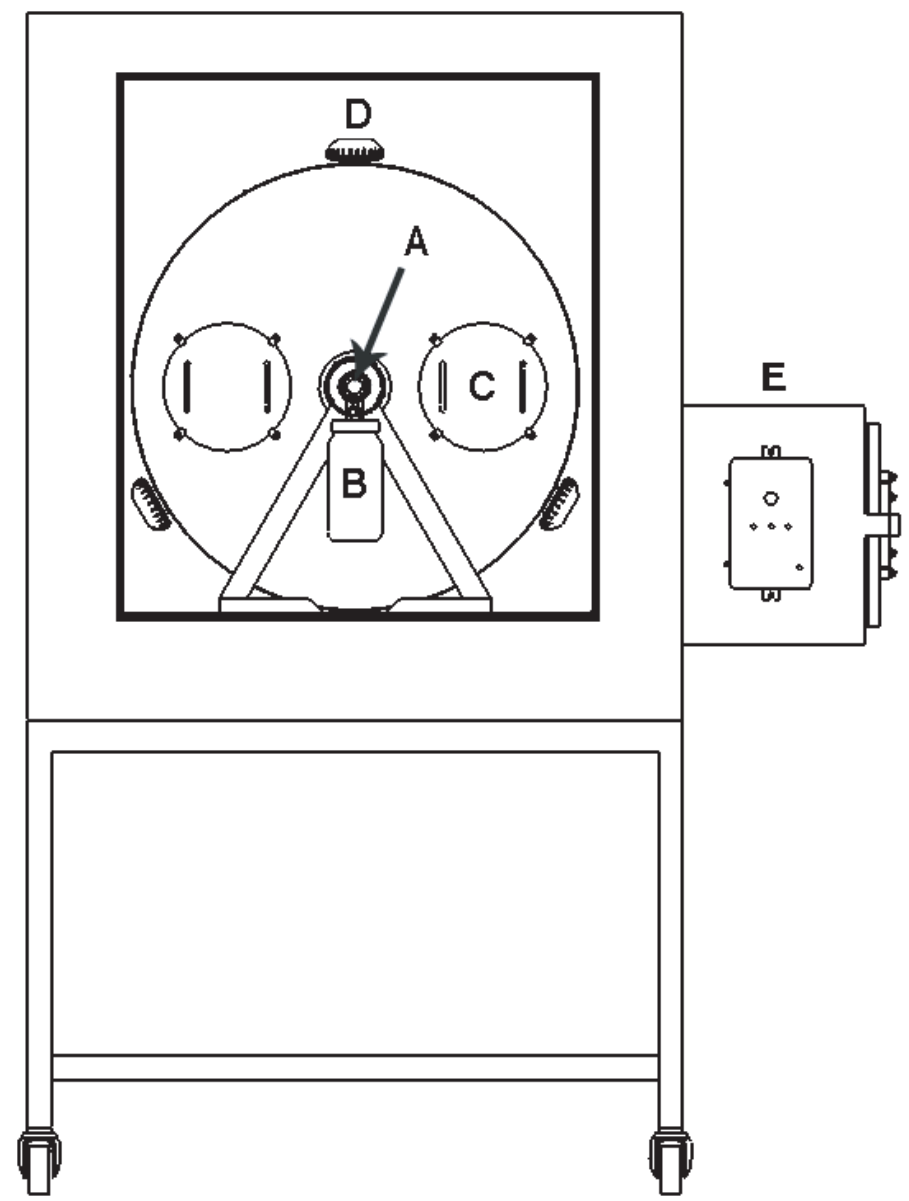

Figure 1. Dynamic aerosol toroid (DAT) housed in environmental glove box. (A) Port into environmental glove box for introducing and sampling aerosol cloud. (B) Placement of 24-jet Collison nebulizer for introducing aerosol or SKC BioSampler ${ }^{\circledR}$ impinger for sampling aerosol on outside of glove box. (C) Airtight access panel for decontamination of DAT. (D) Externally mounted hepafilters $(n=3)$ to filter makeup air during nebulization and impingement. (E) Airlock pass-thorough chamber and control panel for remote operation of DAT.

probe (Vaisala, HMP46, Helsinki, Finland) connected to a temperature and humidity indicator (Vaisala, HMI41) inserted into the DAT.

\subsection{Aerosolization of PRRSV}

Suspension fluid consisting of $10 \mathrm{~mL}$ of stock PRRSV $\left(1 \times 10^{6.33} \mathrm{TCID}_{50} / \mathrm{mL}\right)$,
$40 \mathrm{~mL}$ sterile PBS (1X) (Invitrogen, 10010-064, Carlsbad, CA, USA), $0.1 \%$ (v/v) Rhodamine B dye (Sigma Chemical Co., R6626), and 0.01\% (v/v) Antifoam A Emulsion (Sigma Chemical Co., A5758) was aerosolized into the DAT using a 24-jet Collison nebulizer (BGI Inc., CN60, Waltham, MA, USA). Previous research showed that Antifoam A Emulsion was non-virucidal for PRRSV [19]. The 
nebulizer was operated for $3 \mathrm{~min}$ on compressed air (Sears Roebuck, 00916734000 , Hoffman Estates, IL, USA) at 40 P.S.I. producing: $80 \mathrm{~L}$ of free air per minute, a liquid generation rate of $66 \mathrm{~mL} / \mathrm{h}$, and a particle size of $1.9 \mu \mathrm{m}$ [30]. The cloud was allowed to stabilize for $1 \mathrm{~min}$ before sampling.

\subsection{Impingers}

SKC BioSampler ${ }^{\circledR} \quad$ (SCK Inc., 225-9595, Eighty Four, PA, USA) impingers were used to collect samples from the DAT. Each impinger contained $20 \mathrm{~mL}$ of sterile PBS (1X) collection fluid and was operated for $1 \mathrm{~min}$. Impingers were operated at a vacuum pressure of $\leq(-0.05)$ ATM to ensure a constant flow rate of $12.5 \mathrm{~L}$ per minute $(\mathrm{L} / \mathrm{min})$. Flow rate was verified using a flow meter (Dwyer Instruments Inc., DW-806). Vacuum pressure was maintained using oil-less pumps (Fisher Scientific, S413801) and was monitored using a vacuum pressure gauge (Cato Western Inc., G-S4LM20-VAC-100, Tucson, AZ, USA).

\subsection{Sampling of aerosolized PRRSV}

A total of six samples were taken over the course of each replicate. The first sample was collected one minute postnebulization. Thereafter, depending on the temperature, samples were collected at intervals appropriate to monitor the loss of infectivity over time. Since aerosolized infectious virus was more stable at lower temperature, the time interval between samples was greater at cooler temperatures than at warmer temperatures. Impinger samples were aliquoted into three $5 \mathrm{~mL}$ portions. Individual aliquots were used for: (1) microinfectivity assay ( TCID $_{50}$ ) to determine the titer of infectious PRRSV;
(2) quantitative reverse-transcriptase polymerase chain reaction (RT-PCR) to determine total PRRSV RNA; (3) fluorometric analysis to determine the concentration of Rhodamine B. Microinfectivity and fluorometric analyses were performed immediately. Samples to be assayed by RT-PCR were frozen at $-80{ }^{\circ} \mathrm{C}$, completely randomized, and then submitted for analysis as a single set of samples.

\subsection{Microinfectivity assay (TCID $\left.{ }_{50}\right)$}

PRRSV was titrated on 96-well plates (Corning ${ }^{\circledR}$, 3596) containing confluent 24 h-old MARC-145 cells. Samples containing virus were serially 10 -fold diluted $\left(10^{0}\right.$ to $\left.10^{-5}\right)$ in MEM. Growth medium was discarded and 8 wells were inoculated with $100 \mu \mathrm{L}$ of sample at each dilution. After incubating for $2 \mathrm{~h}$, the inoculum was discarded and $200 \mu \mathrm{L}$ of maintenance medium was added to each well. Plates were incubated at $37{ }^{\circ} \mathrm{C}$ in a humidified $5 \% \quad \mathrm{CO}_{2}$ incubator for 48 h. Following incubation, cells were fixed with aqueous $80 \%$ acetone solution and stained with a fluorescein isothiocyanate-conjugated monoclonal antibody specific for PRRSV (SDOW17, Rural Technologies, Inc., Brookings, SD, USA). Virus titers were calculated on the basis of the number of wells showing a PRRSV-specific fluorescence reaction at each dilution using the Spearman-Kärber method [21] and expressed as tissue culture infection dose $50\left(\mathrm{TCID}_{50}\right)$ per $\mathrm{mL}$.

\subsection{Polymerase chain reaction}

PRRSV RNA for real-time RT-PCR amplification was extracted from $0.14 \mathrm{~mL}$ of sample with a QIAamp viral RNA minikit (Qiagen Inc., 210210, Valencia, CA, USA) following the protocols recommended by the manufacturer. Real-time 
RT-PCR quantification was performed using an ABI Prism ${ }^{\circledR} 7900$ HT Sequence Detection System (Applied Biosystems, Foster City, CA, USA). Primers specific for PRRSV ORF7 were synthesized by Integrated DNA Technologies (Coralville, IA, USA) and MGB probes were synthesized by Applied Biosystems. The thermal profile for amplification of PRRSV RNA was a reverse transcription at $50{ }^{\circ} \mathrm{C}$ for $30 \mathrm{~min}$, followed by enzyme activation at $95^{\circ} \mathrm{C}$ for $15 \mathrm{~min}$, then 40 cycles of denaturation at $94{ }^{\circ} \mathrm{C}$ for $15 \mathrm{~s}$ and a combined annealing/extension step at $60{ }^{\circ} \mathrm{C}$ for $60 \mathrm{~s}$. For each assay, a standard curve was generated using standards containing PRRSV at $10^{1}$ to $10^{6} \mathrm{TCID}_{50}$ per $\mathrm{mL}$ and positive and negative control samples were included for quality control of the test with the unknowns.

\subsection{Tracer quantification}

Rhodamine B was used to quantify the physical loss of the aerosolized cloud containing PRRSV in the DAT through sedimentation over time [14, 22, 37, 39]. Impinger samples were transferred into cuvettes (Fisher Scientific, 14-385-942) and quantified using a fluorometer (9200-000, Turner BioSystems Inc., Sunnyvale, CA, USA) equipped with a green optical kit (9200-042, Turner BioSystems Inc.). The result was expressed in terms of the concentration of Rhodamine B present in the sample in parts per billion (PPB).

\subsection{Statistical analysis}

Within the DAT, infectious virus was lost over time through biological decay and physical loss due to sedimentation of airborne particles [16]. To calculate the biological decay of aerosolized infectious virus, it was necessary to adjust for the physical loss of infectious virus due to sedimentation, i.e., biological decay $=$ total decay - physical loss. Using the concentration of Rhodamine B as a measure of physical loss [14, 22, 37, 39], the adjusted PRRSV infectious titers for each sample were estimated as shown in Equation (1), where subscripts represent time zero $(0)$ or time " $t$ ".

Adjusted infectious virus titer $=$

$$
\frac{\text { TCID }_{50} \text { time } t}{\left(\frac{\text { tracer } \text { concentration time } t}{\text { tracer concentration time } 0}\right)}
$$

Thereafter, the adjusted infectious PRRSV titers $\left(\log _{10}\right)$ for the six sampling points were plotted against time. Subsequently, the $T 1 / 2$ of PRRSV for each of the 18 experimental runs was calculated using linear regression analysis, as described by Bryan et al. [5]. Using the calculated $T 1 / 2$ from the experimental runs, a non-linear regression model was selected to predict $T 1 / 2$ at various temperature and relative humidity combinations. The model allowed for exponential decay of $T 1 / 2$ using Equation (2).

$$
y_{i}=\alpha \mathrm{e}^{-\left(\delta \times T_{e m p}+\gamma \times R H_{i}\right)}+\varepsilon_{i},
$$

where $y_{i}$ represented the $T 1 / 2$ for observation $i, \alpha$ was the intercept, and $\delta$ and $\gamma$ represented the effect of temperature and relative humidity, respectively. All modeling was done using commerciallyavailable statistical software (S-Plus 6.2, Insightful Corp., Seattle, WA, USA).

The relationship between physical loss of the virus cloud and total detectable viral RNA was evaluated by comparing quantitative RT-PCR estimates of PRRSV RNA to quantitative (fluorometer) estimates of Rhodamine B dye in samples collected over time. To compare RT-PCR estimates of PRRSV concentration in TCID $_{50}$ equivalents to fluorometer estimates of Rhodamine B concentration in PPB, estimates for each sampling point were converted to a percent of the concentration in the cloud at time zero. This is shown in Equation (3), 
where "value" was either Rhodamine B concentration in PPB or concentration of PRRSV RNA in TCID $_{50}$ equivalents and subscripts represent time zero (0) or sample time " $t$ ".

$$
\text { Percent time }(t)=\frac{\text { value time } t}{\text { value time } 0} \times 100
$$

The difference between percent time $(t)$ Rhodamine B and percent time $(t)$ PRRSV RNA was calculated by subtracting one from the other. The difference was plotted against time (min) for all sampling points and the slope of the line was derived by linear regression analysis. The slope of the regression line was compared to a slope of zero using analysis of variance.

\section{RESULTS}

The experimental results showed that aerosolized PRRSV was least stable $(T 1 / 2=3.6 \mathrm{~min})$ at $41.0{ }^{\circ} \mathrm{C}$ and $73.0 \%$ relative humidity and most stable $(T 1 / 2=$ $192.7 \mathrm{~min}$ ) at $5.0{ }^{\circ} \mathrm{C}$ and $17.1 \%$ relative humidity (Tab. I). In general, longer $T 1 / 2$ was associated with lower environmental temperature (Fig. 2) and/or lower relative humidity (Fig. 3). A non-linear regression model revealed that the effects of temperature $(p<0.001)$ and relative humidity ( $p=0.003$ ) on the $T 1 / 2$ of airborne PRRSV were statistically significant, but the interaction between temperature and relative humidity was not $(p=0.21)$. Based on this model, an equation was derived with which the $T 1 / 2$ of aerosolized PRRSV can be predicted for any combination of environmental temperature and relative humidity (Eq. (4)).

$$
T 1 / 2=339.037 \mathrm{e}^{(-0.0839 \times T e m p)+(-0.00754 \times R H)}
$$

Estimates of PRRSV T1/2 for a range of temperature and relative humidity combinations is reported in Table II.
No statistical difference was detected between the percent time $(t)$ of Rhodamine B and the percent time $(t)$ PRRSV RNA by linear regression analysis ( $p=$ 0.99) (Fig. 4). This provided evidence that, under the conditions of this experiment, the decline in total PRRSV RNA was due to sedimentation and physical loss of particles, rather than degradation of viral RNA.

\section{DISCUSSION}

Airborne transmission of viruses is a function of (1) the rate at which airborne virus is generated by infected hosts or other sources, (2) the stability $(T 1 / 2)$ of infectious virus in aerosols, and (3) the virus dose required to infect a susceptible host via aerosol exposure. A key component in the process of aerosol transmission, $T 1 / 2$ reflects the likelihood that airborne virus will remain infectious a sufficient length of time to reach a susceptible host.

The $T 1 / 2$ of infectious viruses in aerosols is affected by environmental factors, especially relative humidity and temperature $[9,14,22,33,38]$. In general, airborne viruses are more stable at lower temperatures, but viruses are not uniformly affected by environmental factors. For example, viruses with lipoprotein envelopes tend to be more stable at lower relative humidity and non-enveloped viruses more stable at higher relative humidity $[1,2,10$, 12-14, 27, 36, 39].

Consistent with these general trends, this experiment showed that PRRSV was more stable at lower temperatures and/or lower relative humidity. However, temperature exerted a greater effect on $T 1 / 2$ than relative humidity. That is, at lower temperatures the effect of different levels of relative humidity on $T 1 / 2$ at low temperatures was distinct and measurable, but at higher temperatures the effect of levels of relative humidity on PRRSV T1/2 was obscured by the rapid loss of virus infectivity 
Table I. Observed half-lives of aerosolized infectious PRRSV by temperature and relative humidity.

\begin{tabular}{lcc}
\hline Temperature $^{\mathrm{a}}\left({ }^{\circ} \mathrm{C}\right)$ & Relative humidity $^{\mathrm{a}}(\%)$ & Observed half-life $^{\mathrm{b}}(\mathrm{min})$ \\
\hline 5.0 & 17.1 & 192.7 \\
5.0 & 70.0 & 118.9 \\
8.0 & 80.0 & 82.3 \\
10.0 & 6.0 & 149.5 \\
13.0 & 71.0 & 87.3 \\
13.0 & 84.0 & 70.1 \\
15.0 & 17.0 & 97.3 \\
15.0 & 44.1 & 80.2 \\
20.0 & 20.0 & 29.9 \\
20.0 & 30.0 & 29.3 \\
20.0 & 56.0 & 94.1 \\
25.0 & 20.0 & 17.6 \\
25.0 & 50.0 & 23.8 \\
25.0 & 90.0 & 19.0 \\
30.0 & 30.3 & 4.1 \\
30.0 & 63.8 & 3.3 \\
41.0 & 5.0 & 5.6 \\
41.0 & 73.0 & 3.6 \\
\hline
\end{tabular}

a Temperature and relative humidity was measured using a probe connected to a temperature and humidity indicator.

$\mathrm{b}$ Observed half-life was calculated using linear regression analysis of $\mathrm{TCID}_{50}$ data collected from dynamic aerosol torrid.

(Figs. 2 and 3). Based on the results of this experiment, an equation was derived to predict PRRSV $T 1 / 2$ for any combination of temperature and relative humidity:

$T 1 / 2=339.037 \mathrm{e}^{(-0.0839 \times T e m p)+(-0.00754 \times R H)}$

Temperature and relative humidity are highly variable among geographic locations [24] and by season [20]. Indeed, temperature and relative humidity often vary greatly throughout the day. Given that $T 1 / 2$ is highly dependent upon temperature and relative humidity, it should be expected that the likelihood of aerosol transmission of PRRSV will vary by geographic location, season, and even throughout the day. Depending on specific local conditions, i.e. herd sizes, herd density, and climate, it is possible that aerosol transmission could be a significant route of PRRSV transmission in some regions of the world and not in others.

The use of quantitative RT-PCR made it possible to monitor the presence of aerosolized PRRSV viral RNA independent from infectivity assays. In contrast to infectious PRRSV, PRRSV RNA was stable under the conditions evaluated in this study. Thus, a comparison of viral RNA and Rhodamine B dye, a physical tracer, found no significant difference in the slopes of the lines. This indicated that the loss of PRRSV RNA over time was due to sedimentation from the viral cloud, not decay of viral RNA. These results suggested that quantitative RT-PCR could be 


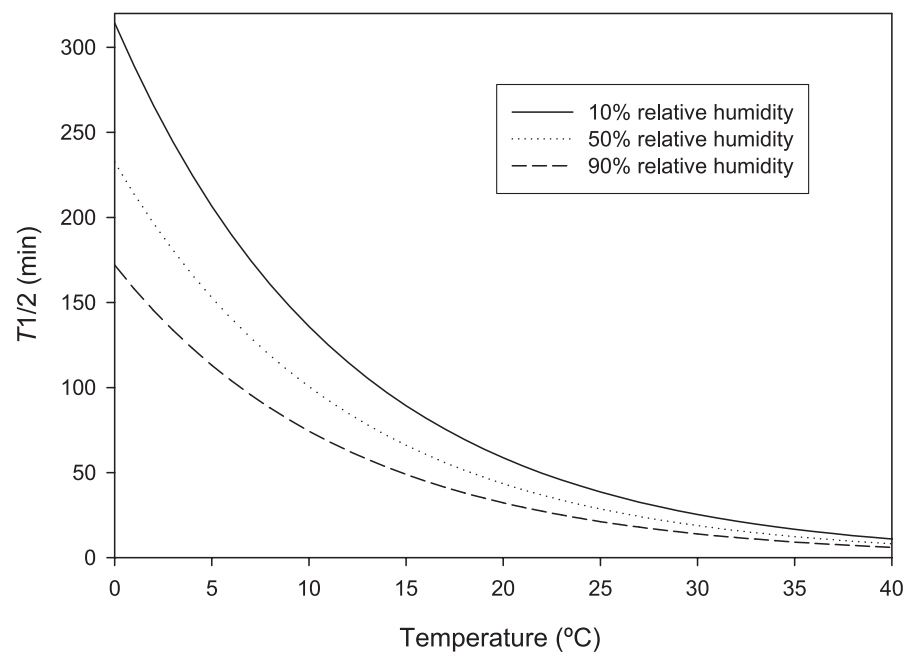

Figure 2. Predicted effect of temperature on half-life of aerosolized infectious PRRSV at $10 \%$, $50 \%$, and $90 \%$ relative humidity.



Figure 3. Predicted effect of relative humidity on half-life of aerosolized infectious PRRSV at 10, 20 , and $30^{\circ} \mathrm{C}$.

used as an ancillary measurement of physical loss of virus in future aerosol studies. However, there are no estimates on degradation of viral RNA in aerosols and it would be premature to substitute quantitative PCR estimates for a physical tracer, or abandon the use of physical tracers, until such estimates are available.
An equally important observation was that quantitative RT-PCR results are independent of the quantity of infectious virus. Thus, it is not possible to interpret RT-PCR results in the context of the potential for virus transmission. Therefore, quantitative RT-PCR assays are extremely useful for laboratory stability studies, but 
Table II. Predicted half-lives of aerosolized infectious PRRSV by temperature and relative humidity combinations ( $\mathrm{min})$.

\begin{tabular}{lccccccccc}
\hline $\begin{array}{l}\text { Temperature } \\
\left({ }^{\circ} \mathrm{C}\right)\end{array}$ & 10 & 20 & 30 & 40 & 50 & 60 & 70 & 80 & 90 \\
\cline { 2 - 10 } & $214.6^{\mathrm{a}}$ & 206.7 & 177.8 & 164.8 & 152.9 & 141.8 & 131.5 & 121.9 & 113.1 \\
5 & 135.9 & 126.0 & 116.9 & 108.4 & 100.5 & 93.2 & 86.4 & 80.2 & 74.3 \\
10 & 89.3 & 82.8 & 76.8 & 71.2 & 66.0 & 61.2 & 56.8 & 52.7 & 48.9 \\
15 & 58.7 & 54.5 & 50.5 & 46.8 & 43.4 & 40.3 & 37.3 & 34.6 & 32.1 \\
20 & 38.6 & 35.8 & 33.2 & 30.8 & 28.5 & 26.5 & 24.6 & 22.8 & 21.1 \\
25 & 25.4 & 23.5 & 21.8 & 20.2 & 18.8 & 17.4 & 16.1 & 15.0 & 13.9 \\
30 & 16.7 & 15.5 & 14.3 & 13.3 & 12.3 & 11.4 & 10.6 & 9.8 & 9.1 \\
35 & 11.0 & 10.2 & 9.4 & 8.7 & 8.1 & 7.5 & 7.0 & 6.5 & 6.0 \\
40 & & & & & & & & &
\end{tabular}

${ }^{a}$ Predicted half-life was calculated using a non-linear regression model.

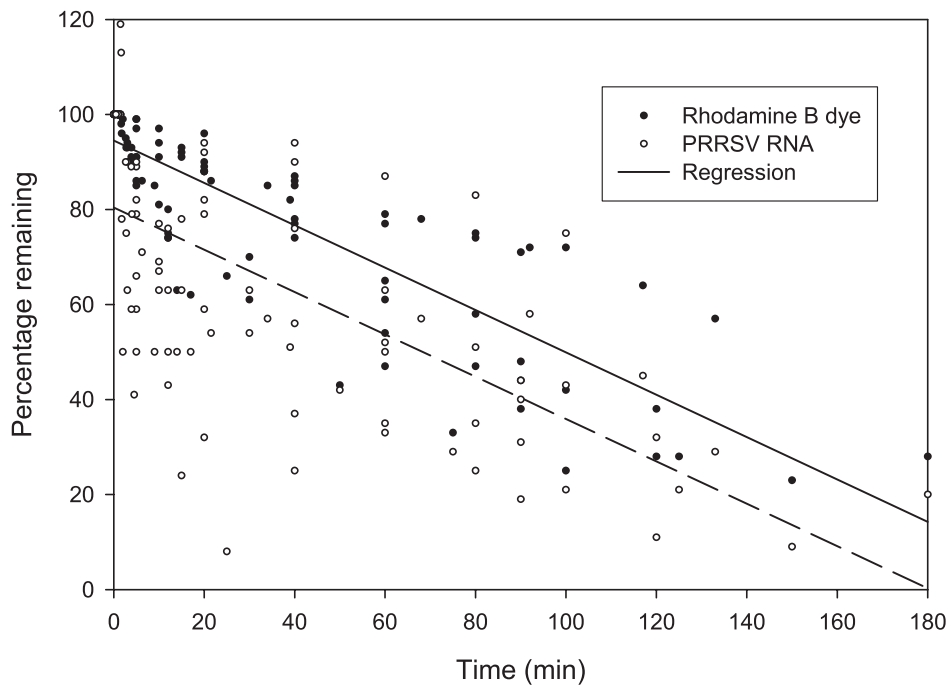

Figure 4. Percentage of Rhodamine B dye and PRRSV RNA remaining out of total aerosolized over time.

detection of viruses in field samples using RT-PCR should be interpreted judiciously in the context of the potential for virus transmission.

Overall, the PRRSV T1/2 estimates reported begin to provide a quantitative basis for evaluating the risk of airborne transmission of PRRSV. Environmental conditions not evaluated in this experiment that may affect $T 1 / 2$ of airborne PRRSV include ultraviolet radiation, wind speed, airborne debris, particle size, and composition of droplet. In addition to estimates on airborne stability, estimates on the quantity of PRRSV aerosolized by pigs and the dose required to infect susceptible animals is 
required to fully understand the likelihood of aerosol transmission and the circumstances under which it occurs.

\section{ACKNOWLEDGEMENTS}

This project was funded in part by Check-Off Dollars through the National Pork Board. Glove box equipment was provided by Boehringer Ingelheim (Vetmedica, Inc., St. Joseph, Missouri, USA). Special thanks to Mike Harper and Terry Herrman (Ames Laboratory, Iowa State University, USA) for engineering the construction of the DAT.

\section{REFERENCES}

[1] Adams D., Spendlove J., Spendlove R., Barnett B., Aerosol stability of infectious and potentially infectious reovirus particles, Appl. Environ. Microbiol. (1982) 44:903-908.

[2] Akers T., Bond S., Goldberg L., Effect of temperature and relative humidity on survival of airborne Columbia-SK group viruses, Appl. Microbiol. (1966) 14:361-364.

[3] Benfield D., Nelson C., Steffen M., Rowland R., Transmission of PRRSV by artificial insemination using extended semen seeded with different concentrations of PRRSV, in: Proceedings of the American Association of Swine Practitioners, 2000, pp. 405-408.

[4] Brockmeier S.L., Lager K.M., Experimental airborne transmission of porcine reproductive and respiratory syndrome virus and Bordetella bronchiseptica, Vet. Microbiol. (2002) 89:267-275.

[5] Bryan M., Zimmerman J., Berry W., The use of half-lives and associated confidence intervals in biological research, Vet. Res. Commun. (1990) 14:235-240.

[6] Cavanagh D., Nidovirales: A new order comprising Coronaviridae and Ateriviridae, Arch. Virol. (1997) 142:629-633.

[7] Christianson W., Choi C., Collins J., Molitor T., Morrison R., Joo H., Pathogenesis of porcine reproductive and respiratory syndrome virus infection in mid-gestation sows and fetuses, Can. J. Vet. Res. (1993) 57:262-268.
[8] Conzelmann K., Visser N., Van Woensel P., Thiel H., Molecular characterization of porcine reproductive and respiratory syndrome virus a member of the arterivirus group, Virology (1993) 193:329-339.

[9] Davies E., Beran G., Influence of environmental factors upon the survival of Aujeszky's disease virus, Res. Vet. Sci. (1981) 31:32-36.

[10] De Jong J., Harmsen M., Trouwborst T., Factors in the inactivation of encephalomyocarditis virus in aerosols, Infect. Immun. (1975) 12:29-35.

[11] Dee S., Batista L., Deen J., Pijoan C., Evaluation of an air-filtration system for preventing aerosol transmission of porcine reproductive and respiratory syndrome virus, Can. J. Vet. Res. (2005) 69:293-298.

[12] Donaldson A., Ferris N., The survival of some airborne animal viruses in relation to relative humidity, Vet. Microbiol. (1976) 1:413-420.

[13] Ehrlich R., Miller S., Effect of relative humidity and temperature on airborne Venezuelan equine encephalitis virus, Appl. Microbiol. (1971) 22:194-199.

[14] Elazhary M., Derbyshire J., Effect of temperature relative humidity and medium on the aerosol stability of infectious bovine rhinotracheitis virus, Can. J. Comp. Med. (1979) 43:158-167.

[15] Fano E., Pijoan C., Dee S., Evaluation of the aerosol transmission of a mixed infection of Mycoplasma hyopneumoniae and porcine reproductive and respiratory syndrome virus, Vet. Rec. (2005) 157:105-108.

[16] Goldberg L.J., Watkins H.M., Boerke E.E., Chatigny M.A., The use of a rotating drum for the study of aerosols over extended periods of time, Am. J. Hyg. (1958) 68:85-93.

[17] Gradil C., Dubuc C., Eaglesome M., Porcine reproductive and respiratory syndrome virus: Seminal transmission, Vet. Rec. (1996) 138:521-522.

[18] Hermann J.R., Munoz-Zanzi C.A., Roof M.B., Burkhart K., Zimmerman J.J., Probability of porcine reproductive and respiratory syndrome (PRRS) virus infection as a function of exposure route and dose, Vet. Microbiol. (2005) 110:7-16.

[19] Hermann J.R., Hoff S.J., Yoon K.J., Burkhardt A.C., Evans R.B., Zimmerman J.J., Optimization of a sampling system for recovery and detection of airborne porcine reproductive and respiratory syndrome virus 
and swine influenza virus, Appl. Environ. Microbiol. (2006) 72:4811-4818.

[20] Honeyman M.S., Harmon J.D., Performance of finishing pigs in hoop structures and confinement during winter and summer, J. Anim. Sci. (2003) 81:1663-1670.

[21] Hubert J.J., Bioassays, 3rd ed., Kendall/Hunt Publishing Co., Iowa, 1992, pp. 73-76.

[22] Ijaz M.K., Karim Y.G., Sattar S.A., JohnsonLussenburg C.M., Development of methods to study the survival of airborne viruses, J. Virol. Methods (1987) 18:87-106.

[23] Kim H.S., Kwang J., Yoon I.J., Joo H.S., Frey M.L., Enhanced replication of porcine reproductive and respiratory syndrome (PRRS) virus in a homogenous subpopulation of MA-104 cells, Arch. Virol. (1993) 133:477-483.

[24] Kovats R.S., Edwards S.J., Charron D., Cowden J., D'Souza R.M., Ebi K.L., Gauci C., Gerner-Smidt P., Hajat S., Hales S., Hernandez Pezzi G., Kriz B., Kutsar K., McKeown P., Mellou K., Menne B., O’Brien S., van Pelt W., Schmid H., Climate variability and campylobacter infection: an international study, Int. J. Biometeorol. (2005) 49:207-214.

[25] Kristensen C.S., Botner A., Takai H., Nielsen J.P., Jorsal S.E., Experimental airborne transmission of PRRS virus, Vet. Microbiol. (2004) 99:197-202.

[26] Lager K.M., Mengeling W.L., Experimental aerosol transmission of pseudorabies virus and porcine reproductive and respiratory syndrome virus, in: Proceedings of the American Association of Swine Practitioners, 2000, pp. 409-410.

[27] Larson E.W., Dominik J.W., Slone T.W., Aerosol stability and respiratory infectivity of Japanese B encephalitis virus, Infect. Immun. (1980) 30:397-401.

[28] Magar R., Robinson Y., Dubuc C., Larochelle R., Isolation and experimental oral transmission in pigs of a porcine reproductive and respiratory syndrome virus isolate, Adv. Exp. Med. Biol. (1995) 380:139-144.

[29] Magar R., Larochelle R., Evaluation of the presence of porcine reproductive and respiratory syndrome virus in pig meat and experimental transmission following oral exposure, Can. J. Vet. Res. (2004) 68:259-266.

[30] May K.R., The Collison Nebulizer description performance and application, J. Aerosol Sci. (1973) 4:235.

[31] Meredith M.J., "Blue ear" disease epidemic, Pig News Inf. (1991) 12:363.

[32] Meulenberg J., Hulst M., de Meuer E., Moonen P., den Besten A., de Kluyver E., Wensvoort G., Moormann R., Lelystad virus the causative agent of porcine epidemic abortion and respiratory syndrome (PEARS) is related to LDV and EAV, Virology (1993) 192:62-72.

[33] Moe K., Harper G.J., The effect of relative humidity and temperature on the survival of bovine rotavirus in aerosol, Arch. Virol. (1983) 76:211-216.

[34] Neumann E.J., Kliebenstein J.B., Johnson C.D., Mabry J.W., Bush E., Seitzinger A.H., Green A., Zimmerman J.J., Assessment of the economic impact of porcine reproductive and respiratory syndrome on swine production in the United States, J. Am. Vet. Med. Assoc. (2005) 227:385-392.

[35] Pringle C.R., Virus taxonomy 1996 - A bulletin from the Xth International Congress of Virology in Jerusalem, Arch. Virol. (1996) 141:2251-2256.

[36] Rabey F., Janssen R.J., Kelley L.M., Stability of St. Louis encephalitis virus in the airborne state, Appl. Microbiol. (1969) 18:880-882.

[37] Sattar S.A., Ijaz M.K., Johnson-Lussenburg C.M., Springthorpe V.S., Effect of relative humidity on the airborne survival of rotavirus SA11, Appl. Environ. Microbiol. (1984) 47:879-881.

[38] Schoenbaum M.A., Zimmerman J.J., Beran G.W., Murphy D.P., Survival of pseudorabies virus in aerosol, Am. J. Vet. Res. (1990) 51:331-333.

[39] Songer J.R., Influence of relative humidity on the survival of some airborne viruses, Appl. Microbiol. (1967) 15:35-42.

[40] Torremorell M., Pijoan C., Janni K., Walker J., Joo H.S., Airborne transmission of Actinobacillus pleuropneumoniae and porcine reproductive and respiratory syndrome virus in nursery pigs, Am. J. Vet. Res (1997) 58:828-832. 
[41] Trincado C., Dee S., Jacobson L., Otake S., Rossow K., Pijoan C., Attempts to transmit porcine reproductive and respiratory syndrome virus by aerosols under controlled field conditions, Vet. Rec. (2004) 154:294-297.

[42] Van der Linden I., van der Linde-Bril E.M., Voermans J., van Rijn P.A., Pol J., Martin R., Steverink P., Oral transmission of porcine reproductive and respiratory syndrome virus by muscle of experimentally infected pigs, Vet. Microbiol. (2003) 97:45-54.

[43] Wills R.W., Zimmerman J.J., Swenson S.L., Yoon K.J., Hill H.T., Bundy D.S., McGinley M.J., Transmission of porcine reproductive and respiratory syndrome virus by direct, close, or indirect contact, Swine Health Prod. (1997) 5:213-218.
[44] Yaeger M.J., Prieve T., Collins J., Christopher-Hennings J., Nelson E., Benfield D., Evidence for the transmission of porcine reproductive and respiratory syndrome (PRRS) virus in boar semen, Swine Health Prod. (1993) 1:7-9.

[45] Yoon K.J., Zimmerman J.J., Chang C.C., Cancel-Tirado S., Harmon K.M., McGinley M.J., Effect of challenge dose and route on porcine reproductive and respiratory syndrome virus (PRRSV) infection in young swine, Vet. Res. (1999) 30:629-638.

[46] Zimmerman J., Epidemiology and ecology, in: Zimmerman J.J., Yoon K.-J. (Eds.), The Porcine Reproductive and Respiratory Syndrome Compendium, 2nd ed., National Pork Board, Des Moines Iowa, 2003, pp. 27-50.

To access this journal online: www.edpsciences.org/vetres 